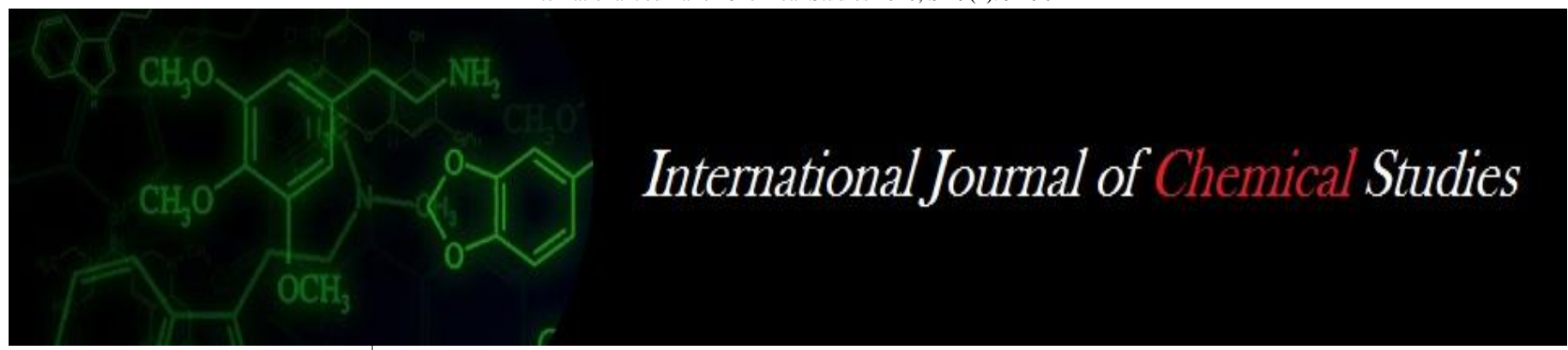

P-ISSN: 2349-8528

E-ISSN: 2321-4902

www.chemijournal.com

IJCS 2021; SP-9(1): 91-96

(C) 2021 IJCS

Received: 13-11-2020

Accepted: 21-12-2020

Kartikey Sahil

Department of Environmental

Science, Dr. YS Parmar

University of Horticulture and

Forestry, Nauni, Solan,

Himachal Pradesh, India

Satish Kumar Bhardwaj

Department of Environmental

Science, Dr. YS Parmar

University of Horticulture and

Forestry, Nauni, Solan,

Himachal Pradesh, India

Rajeev Aggarwal

Department of Environmental

Science, Dr. YS Parmar

University of Horticulture and

Forestry, Nauni, Solan,

Himachal Pradesh, India
Corresponding Author:

Kartikey Sahil

Department of Environmental

Science, Dr. YS Parmar

University of Horticulture and

Forestry, Nauni, Solan,

Himachal Pradesh, India

\section{Assessment of air pollution status in Mandi city and BBN industrial region of Himachal Pradesh}

\author{
Kartikey Sahil, Satish Kumar Bhardwaj and Rajeev Aggarwal
}

DOI: https://doi.org/10.22271/chemi.2021.v9.i1b.11436

\begin{abstract}
In India, over the past two decades, there has been a rapid increase in urbanization and industrialization in many cities. Due to increase in population, vehicular traffic, residential and industrial activities, air pollution levels are increasing day by day even in small cities and towns contiguous to them. Keeping in view the significance of monitoring of air quality the present study was undertaken to assess the ambient air quality status in Mandi and Baddi-Barotiwala-Nalagarh (BBN) region of Himachal Pradesh. The towns had been selected purposely based on residential, commercial, industrial, traffic and tourist activities for the monitoring of the air pollutants. The data has been recorded for eight hours at each location of the selected town during post-monsoon (December-January) season by using Respirable dust sampler (Cat. No MBLRDS-002) and Environmental Perimeter Air Station (EPAS).The observations recorded for air pollutants were respirable suspended particulate matter $\left(\mathrm{PM}_{10}\right), \mathrm{NO}_{2}, \mathrm{SO}_{2}$ and Volatile Organic Compounds (VOCs). Based on the present investigation it was found that the concentrations of gaseous pollutants like $\mathrm{SO}_{2}, \mathrm{NO}_{2}$, volatile organic compounds and particulate matter in the air are within the National Ambient Air Quality Standards at all the sites in Mandi city. The industrial area of HP in Baddi -Barotiwala- Nalagarh also contains gaseous pollutants like $\mathrm{SO}_{2}, \mathrm{NO}_{2}$ and volatile organic compounds within the permissible limits. However, in the Industrial region all sites like Industrial hub, traffic and commercial area contained particulate above the prescribed permissible limits indicating thereby that Industrial activities have started impacting the ambient air quality of our state.
\end{abstract}

Keywords: Urbanization, industrialization, air pollution, suspended particulate matter, gaseous pollutants

\section{Introduction}

The Globalization has led to the rapid growth in the world economy and movement of the people, product, capital etc in a faster and easier manner. Both Industrialization and urbanization are inseparable, just as agriculture fosters villages; industry encourages growth of urban areas (Maheshwari, 2006) ${ }^{[12]}$. Consequently, the world's urbanization rate increased from just under $30 \%$ to over $50 \%$ during the period from 1950-2010. The urban population in almost every country have also been projected to increase in the years to come. It was estimated that by the year 2030 more than $70 \%$ of world people will be living in urban areas. According to the 2011 census, the urban population grew to 377 million showing a growth rate of $2.76 \%$ per annum during 2001-2011. The Indian economy has grown from about $6 \%$ per annum during the 1990 s to about $8 \%$ during the first decade of the 2000 s. This clearly reflects the power of economic growth in bringing about faster urbanization during 2001-2011.

In India, over the past two decades there has been a rapid increase in urbanization and industrialization in many cities. Motor vehicles have been reported to account for 60-70 percent of the pollution in the air in urban environment (Dwivedi et al., 2008) ${ }^{[6]}$. Automobiles are the primary source of air pollution in India's major cities. In India, the number of motor vehicles has grown from 72.7 million in 2004 to approximately 141.8 million in 2011, of which two wheelers (mainly driven by two stroke engines) accounts for approximately $72 \%$ of the total vehicular population. The investigation by Mage et al. (1996) ${ }^{[11]}$ indicates that motor traffic is a major source of air pollution in mega cities. Fossil fuels burnt by motor vehicles contribute 90 percent to urban air pollution including lead, carbon monoxide, ozone and suspended particulate matter. The regional emissions of sulphur dioxide are expected to increase fourfold by 2030 over those of 1990 whereas emissions of nitrogen oxides are expected to increase three-fold (Anonymous, 2000) ${ }^{[1]}$. 
Rapid urbanization and growth of motor vehicles impose a serious effect on human life and its environment in recent years. Most of the cities of India are being suffered by extremely high level of urban air pollution particularly in the form of $\mathrm{CO}, \mathrm{SO}_{2}, \mathrm{NO}_{2}, \mathrm{PM}$ (Particulate Matter) and RSPM (Respirable Suspended Particulate Matter). Transport sector contributes a major share to environmental pollution (around $70 \%)$. Urban ambient air pollution is the result of emissions from a multiplicity of sources, mainly stationary, industrial and domestic fossil fuel combustion, petrol and diesel vehicle emissions (Brulfert et al., 2005 and Parra et al., 2006) ${ }^{[4,17] .}$

Most Asian cities cannot comply with the WHO air quality guidelines or the United State Environmental Protection Agency standards (USEPA); exceptions are cities in more developed countries such as Singapore, Taiwan, and Japan. Several Asian cities in China, India and Vietnam have the highest levels of outdoor air pollution in the world ( $\mathrm{Su}$ et al., 2011) ${ }^{[19]}$. In 1998, National Environment Protection Council (NEPC) made the Ambient Air Quality National Environment Protection Measure (AAQ NEPM) that set national ambient air quality standards to apply in all States and Territories and over land controlled by the Commonwealth. These standards cover six common pollutants are particles $\left(\mathrm{PM}_{10}\right)$, ozone, sulfur dioxide, nitrogen dioxide, carbon monoxide and lead. The World Health Organization (WHO) estimates that air pollution contributes to approximately 800,000 deaths and 4.6 million lost life years annually (Anonymous, 2004) ${ }^{[2]}$. Developing nations are particularly affected by air pollution; as many as two thirds of the deaths and lost life years associated with air pollution on a global scale occur in Asia (Cohen et al., 2004) ${ }^{[5]}$. India need to generate regular information on the ambient concentration levels of small particulates of diameter less than 10 micron and/or 2.5 micron and take urgent steps to control emissions of these particles (Nyberg et al., 2000) [16]. India is now ahead of China and everyone else in having the dubious distinction of having the world's most polluted air.

Air in some Indian cities has particulate matter (PM) levels five times above safety limits. The $\mathrm{PM}_{10}$ levels are the biggest cause of health concern. In 2007, nearly 52\% (63) cities were at critical $\mathrm{PM}_{10}$ levels $\left(\geq 1.5\right.$ times limit). Higher $\mathrm{PM}_{10}$ levels were found in northern Indian cities with continuous increases in Mumbai, Faridabad, Lucknow, Bangalore and Delhi. In recent times, $\mathrm{SO}_{2}$ levels have dropped in most cities except for some high-level areas such as Khurja, Nashik, Jamshedpur and Chandrapur. However, $\mathrm{NO}_{2}$ levels are on the rise all over India because of the rise in the number of vehicles (Smith et al., 2001) ${ }^{[18]}$. The ambient PM concentrations fell quite steadily over the sample timeframe, from $252.1 \mu \mathrm{g} / \mathrm{m}^{3}$ in $1987-1990$ to $209.5 \mu \mathrm{g} / \mathrm{m}^{3}$ in 2004-2010. This represents about a 15 percent reduction in $\mathrm{PM}$. The $\mathrm{SO}_{2}$ trend line is flat until the late 1990 and then declines sharply. Comparing the 19871990 to 2004-2010 time periods, mean $\mathrm{SO}_{2}$ decreased from 19.4 to $12.2 \mu \mathrm{g} / \mathrm{m}^{3}$. $\mathrm{NO}_{2}$ appears more volatile over the start of the sample period, but then falls after its peak in 1997 (Greenstone and Hanna, 2014) ${ }^{[9]}$.

The air quality data generated by the Central Pollution Control Board (CPCB) for 2007 under the National Air Quality Monitoring Programme (NAMP) presents deadly facts about air pollution levels in Indian cities. The national average per capita $\mathrm{SO}_{2}$ emission was $4.2 \mathrm{~kg}$ per person in 1990, which rose to $5 \mathrm{~kg}$ in 1995, an increase of almost $20 \%$ in five year. In 1990, coal consumption contributed $64 \%$ of total /cu-m $\mathrm{SO}_{2}$ emissions in India, oil products $29 \%$, biomass
$4.5 \%$ and non-energy consumption $2.5 \%$ (Garg et al., 2001) [7]. The ambient air quality in Madurai City of South India was studied and it was found that the SPM concentration varied from 200 to $500 \mu \mathrm{g} / \mathrm{cu}-\mathrm{m}, \mathrm{NO}_{\mathrm{X}}$ from 50 to $170 \mu \mathrm{g} / \mathrm{cu}-$ $\mathrm{m}$ and $\mathrm{SO}_{2}$ from 10 to $25 \mu \mathrm{g} / \mathrm{cu}-\mathrm{m}$. The ambient air quality of Jyoti vihar, Orissa in terms of TSP, $\mathrm{SO}_{2}$ and $\mathrm{NO}_{\mathrm{X}}$ was studied during December-1994 to November-1995. The minimum and maximum values were $82.995 \mu \mathrm{g} / \mathrm{cu}-\mathrm{m}$ and $182.7 \mu \mathrm{g} / \mathrm{cu}-$ $\mathrm{m}$ for TSP, $4.62 \mu \mathrm{g} / \mathrm{cu}-\mathrm{m}$ and $25.74 \mu \mathrm{g} / \mathrm{cu}-\mathrm{m}$ for $\mathrm{SO}_{2}$ and 4.39 $\mu \mathrm{g} / \mathrm{cu}-\mathrm{m}$ and $16.89 \mu \mathrm{g} / \mathrm{cu}-\mathrm{m}$ for NOx (Naik, 2005) ${ }^{[15]}$. A report showed that SPM concentrations in Shanghai, New Delhi, Mumbai, Guangzhou, Chongquin, Calcutta, Beijing and Bangkok exceeded WHO limits $(90 \mu \mathrm{g} / \mathrm{cu}-\mathrm{m})$ by three, five, three, three, four, four, four and two times respectively. It also showed that $\mathrm{PM}_{10}$ exceeded the USEPA limit $(50 \mu \mathrm{g} / \mathrm{cu}-\mathrm{m})$ by several times in a number of cities, most notably by over four times in New Delhi and Calcutta (Anonymous, 2007) ${ }^{[3]}$.

Keeping the air quality acceptable has become an important task for decision makers as well as for non-governmental organizations. Particulate matter and gaseous emissions of pollutant emission from industries and auto exhausts are responsible for rising discomfort, increasing airway diseases and deterioration of artistic and cultural patrimony in urban centers (Mukunda et al., 2003) ${ }^{[14]}$. As many cities around the world become more congested, concerns increase over the level of urban air pollution being generated and in particular its impact on localized human health effects such as asthma or bronchitis. In the majority of the developed world, legislation has already been introduced to the extent that local authorities are required by law to conduct regular Local Air Quality Reviews of key urban pollutants such as $\mathrm{SO}_{2}, \mathrm{NO}_{\mathrm{X}}$ or Ozone produced by industrial activity and road transport (Ghanem et al., 2008) ${ }^{[8]}$. There is tremendous increase in vehicular traffic, urbanization, residential and industrial activities in the Mandi city and BBN region. As such, an attempt has been made with an objective to investigate air quality status of the Mandi city and BBN region of Himachal Pradesh.

\section{Methodology}

On the basis of agro-climatic zones different towns which had registered more urbanization and experiencing more population growth and development were selected for the study. The towns had been selected purposely on the basis of residential, commercial, industrial, traffic and tourist activities for the monitoring of the air pollutants.

Survey and sampling of air samples has been done in Mandi town and Baddi-Barotiwala-Nalagarh (BBN) region of Himachal Pradesh. The data has been recorded for eight hours at each location of the selected town during post-monsoon (December-January) season by using Respirable dust sampler (Cat. No MBLRDS-002) and Environmental Perimeter Air Station (EPAS). The observations recorded for air pollutants were respirable suspended particulate matter $\left(\mathrm{PM}_{10}\right), \mathrm{NO}_{2}$, $\mathrm{SO}_{2}$ and Volatile Organic Compounds (VOCs). The data had been analysed with the help of Randomized Block Design using OPSTAT software.

\section{Results}

A study was carried out to assess the status of air pollutants at three selected locations namely residential, commercial and traffic areas during the post monsoon season in the Mandi city and $\mathrm{BBN}$ region of Himachal Pradesh. 


\section{Concentration of air pollutants $\left(\mu \mathrm{g} / \mathrm{m}^{3}\right)$ at different locations in Mandi city during post monsoon season}

Table 1: Concentration of air pollutants $\left(\mu \mathrm{g} / \mathrm{m}^{3}\right)$ at different locations in Mandi city

\begin{tabular}{|c|c|c|c|c|}
\hline \multirow{2}{*}{ Locations } & \multicolumn{3}{|c|}{ Post monsoon } \\
\cline { 2 - 4 } & $\mathbf{P M}_{\mathbf{1 0}}$ & $\mathbf{N O}_{\mathbf{2}}$ & $\mathbf{S O}_{\mathbf{2}}$ & VOCs \\
\hline Residential area & 58.12 & 10.28 & 2.20 & 2.34 \\
\hline Commercial area & 72.40 & 14.06 & 3.50 & 2.56 \\
\hline Mandi Kullu National Highway (Traffic site 1) & 78.40 & 18.12 & 8.60 & 2.80 \\
\hline Mandi -Pathankot National Highway (Traffic site II) & 74.74 & 15.14 & 6.10 & 2.95 \\
\hline ISBT Mandi (Traffic site III) & 78.80 & 20.98 & 6.80 & 3.47 \\
\hline Mean & 72.49 & 15.71 & 5.44 & 2.82 \\
\hline
\end{tabular}

Table 1 showed the concentration of Particulate Matter $\left(\mathrm{PM}_{10}\right)$, Nitrogen dioxide $\left(\mathrm{NO}_{2}\right)$, Sulphur dioxide $\left(\mathrm{SO}_{2}\right)$ and Volatile organic compounds (VOCs) recorded during post monsoon season at different locations in Mandi city. The maximum mean concentration of Particulate Matter $\left(\mathrm{PM}_{10}\right)$ was recorded at traffic site III with a mean value of $78.8 \mu \mathrm{g}$ per $\mathrm{m}^{3}$ followed by traffic site I $\left(78.4 \mu \mathrm{g}\right.$ per $\left.\mathrm{m}^{3}\right)$, traffic site II $\left(74.74 \mu \mathrm{g}\right.$ per $\left.\mathrm{m}^{3}\right)$ and commercial area $\left(72.4 \mu \mathrm{g}\right.$ per $\left.\mathrm{m}^{3}\right)$. The minimum mean concentration of Particulate Matter $\left(\mathrm{PM}_{10}\right)$ was found to be $58.12 \mu \mathrm{g}$ per $\mathrm{m}^{3}$ at residential area. The overall mean concentration of $\mathrm{PM}_{10}$ was found $72.49 \mu \mathrm{g}$ per $\mathrm{m}^{3}$ in the city. The maximum mean concentration of Nitrogen dioxide $\left(\mathrm{NO}_{2}\right)$ was recorded at traffic site III with a mean value of $20.98 \mu \mathrm{g}$ per $\mathrm{m}^{3}$ followed by traffic site I $(18.12 \mu \mathrm{g}$ per $\left.\mathrm{m}^{3}\right)$, traffic site II $\left(15.14 \mu \mathrm{g}\right.$ per $\left.\mathrm{m}^{3}\right)$ and commercial area $\left(14.06 \mu \mathrm{g}\right.$ per $\left.\mathrm{m}^{3}\right)$. The minimum mean concentration of Nitrogen dioxide $\left(\mathrm{NO}_{2}\right)$ was found to be $10.28 \mu \mathrm{g}$ per $\mathrm{m}^{3}$ at residential area in the city. The overall mean concentration of
$\mathrm{NO}_{2}$ was found $15.71 \mu \mathrm{g}$ per $\mathrm{m}^{3}$ in the city. The maximum mean concentration of Sulphur dioxide $\left(\mathrm{SO}_{2}\right)$ was recorded at traffic site I with a mean value of $8.6 \mu \mathrm{g}$ per $\mathrm{m}^{3}$ followed by traffic site III $\left(6.80 \mu \mathrm{g}\right.$ per $\left.\mathrm{m}^{3}\right)$, traffic site II $\left(6.10 \mu \mathrm{g}\right.$ per $\left.\mathrm{m}^{3}\right)$ and commercial area $\left(3.50 \mu \mathrm{g}\right.$ per $\left.\mathrm{m}^{3}\right)$. The minimum mean concentration of Sulphur dioxide $\left(\mathrm{SO}_{2}\right)$ was found to be 2.20 $\mu \mathrm{g}$ per $\mathrm{m}^{3}$ at residential area. The overall mean concentration of $\mathrm{SO}_{2}$ was found $5.44 \mu \mathrm{g}$ per $\mathrm{m}^{3}$ in the city. The maximum mean concentration of Volatile organic compounds (VOCs) was recorded at traffic site III with a mean value of $3.47 \mu \mathrm{g}$ per $\mathrm{m}^{3}$ followed by traffic site II $\left(2.95 \mu \mathrm{g}\right.$ per $\left.\mathrm{m}^{3}\right)$, traffic site I $\left(2.80 \mu \mathrm{g}\right.$ per $\left.\mathrm{m}^{3}\right)$ and commercial area $\left(2.56 \mu \mathrm{g}\right.$ per $\left.\mathrm{m}^{3}\right)$. The minimum mean concentration of Volatile organic compounds (VOCs) was found to be $2.34 \mu \mathrm{g}$ per $\mathrm{m}^{3}$ at residential area. The overall mean concentration of VOCs was found $2.82 \mu \mathrm{g}$ per $\mathrm{m}^{3}$ in the city. Figure 1 show the concentration of air pollutants $\left(\mu \mathrm{g} / \mathrm{m}^{3}\right)$ at different locations in Mandi city.

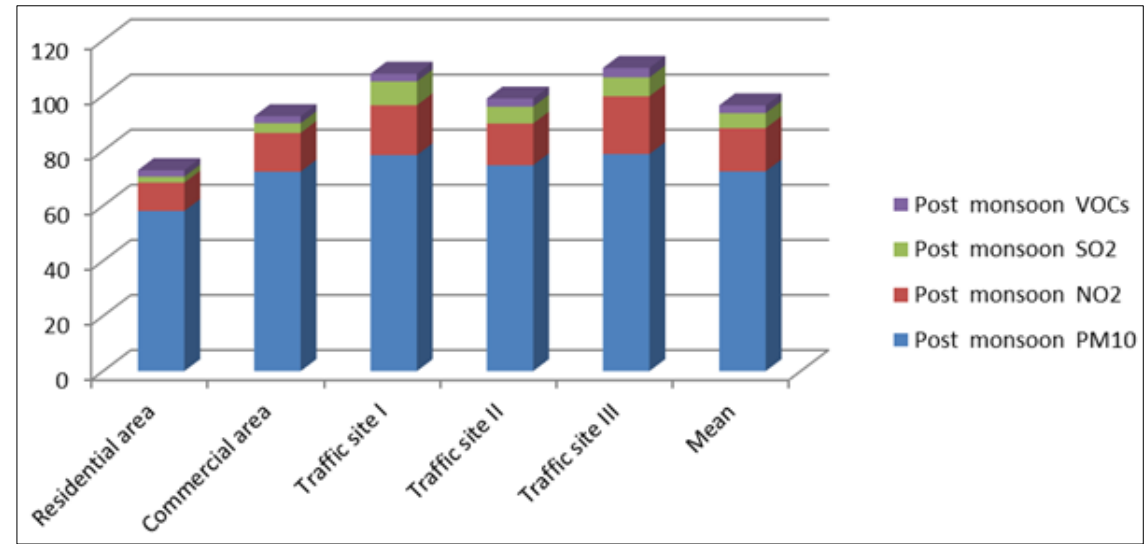

Fig 1: Concentration of air pollutants $\left(\mu \mathrm{g} / \mathrm{m}^{3}\right)$ at different locations in Mandi city

Concentration of air pollutants $\left(\mu \mathrm{g} / \mathrm{m}^{3}\right)$ at different locations in Baddi-Barotiwala-Nalagarh (BBN) region during post monsoon season

Table 2: Concentration of air pollutants $\left(\mu \mathrm{g} / \mathrm{m}^{3}\right)$ at different locations in Baddi

\begin{tabular}{|c|c|c|c|c|}
\hline \multirow{2}{*}{ Locations } & \multicolumn{4}{|c|}{ Post monsoon } \\
\cline { 2 - 5 } & $\mathbf{P M}_{\mathbf{1 0}}$ & $\mathbf{N O}_{\mathbf{2}}$ & $\mathbf{S O}_{\mathbf{2}}$ & VOCs \\
\hline Residential area & 80.01 & 31.01 & 6.40 & 4.06 \\
\hline Commercial area & 168.22 & 44.07 & 7.47 & 6.08 \\
\hline Industrial area & 188.23 & 54.08 & 12.08 & 8.06 \\
\hline Traffic area & 172.70 & 47.47 & 10.09 & 7.74 \\
\hline Mean & 152.29 & 44.15 & 9.01 & 6.48 \\
\hline
\end{tabular}

The data presented in table 2 showed the concentration of Particulate Matter $\left(\mathrm{PM}_{10}\right)$, Nitrogen dioxide $\left(\mathrm{NO}_{2}\right)$, Sulphur dioxide $\left(\mathrm{SO}_{2}\right)$ and Volatile organic compounds (VOCs) recorded during post monsoon season at different locations in
Baddi city. The maximum mean concentration of Particulate Matter $\left(\mathrm{PM}_{10}\right)$ was recorded at industrial area with a mean value of $188.23 \mu \mathrm{g}$ per $\mathrm{m}^{3}$ followed by traffic area $(172.70 \mu \mathrm{g}$ per $\left.\mathrm{m}^{3}\right)$ and commercial area $\left(168.22 \mu \mathrm{g}\right.$ per $\left.\mathrm{m}^{3}\right)$. The minimum mean concentration of Particulate Matter $\left(\mathrm{PM}_{10}\right)$ was found to be $80.01 \mu \mathrm{g}$ per $\mathrm{m}^{3}$ at residential area. The overall mean concentration of $\mathrm{PM}_{10}$ was found $152.29 \mu \mathrm{g}$ per $\mathrm{m}^{3}$ in the city. The maximum mean concentration of Nitrogen dioxide $\left(\mathrm{NO}_{2}\right)$ was recorded at industrial area with a mean value of $54.08 \mu \mathrm{g}$ per $\mathrm{m}^{3}$ followed by traffic area $(47.47 \mu \mathrm{g}$ per $\mathrm{m}^{3}$ ) and commercial area $\left(44.07 \mu \mathrm{g}\right.$ per $\left.\mathrm{m}^{3}\right)$. The minimum mean concentration of Nitrogen dioxide $\left(\mathrm{NO}_{2}\right)$ was found to be $31.01 \mu \mathrm{g}$ per $\mathrm{m}^{3}$ at residential area in the city whereas the overall mean concentration of $\mathrm{NO}_{2}$ was found $44.15 \mu \mathrm{g}$ per $\mathrm{m}^{3}$ in the city. The maximum mean concentration of Sulphur dioxide $\left(\mathrm{SO}_{2}\right)$ was recorded at industrial area with a mean value of $12.08 \mu \mathrm{g}$ per $\mathrm{m}^{3}$ followed by traffic area $\left(10.09 \mu \mathrm{g}\right.$ per $\left.\mathrm{m}^{3}\right)$ and commercial area $\left(7.47 \mu \mathrm{g}\right.$ per $\left.\mathrm{m}^{3}\right)$. The 
minimum mean concentration of Sulphur dioxide $\left(\mathrm{SO}_{2}\right)$ was found to be $6.40 \mu \mathrm{g}$ per $\mathrm{m}^{3}$ at residential area. The overall mean concentration of $\mathrm{SO}_{2}$ was found $9.01 \mu \mathrm{g}$ per $\mathrm{m}^{3}$ in the city. The maximum mean concentration of Volatile organic compounds (VOCs) was recorded at industrial area with a mean value of $8.06 \mu \mathrm{g}$ per $\mathrm{m}^{3}$ followed by traffic area $(7.74$ $\mu \mathrm{g}$ per $\left.\mathrm{m}^{3}\right)$ and commercial area $\left(6.08 \mu \mathrm{g}\right.$ per $\left.\mathrm{m}^{3}\right)$. The minimum mean concentration of Volatile organic compounds (VOCs) was found to be $4.06 \mu \mathrm{g}$ per $\mathrm{m}^{3}$ at residential area while the overall mean concentration of VOCs was found $6.48 \mu \mathrm{g}$ per $\mathrm{m}^{3}$ in the city. Figure 2 show the concentration of air pollutants $\left(\mu \mathrm{g} / \mathrm{m}^{3}\right)$ at different locations in Baddi.

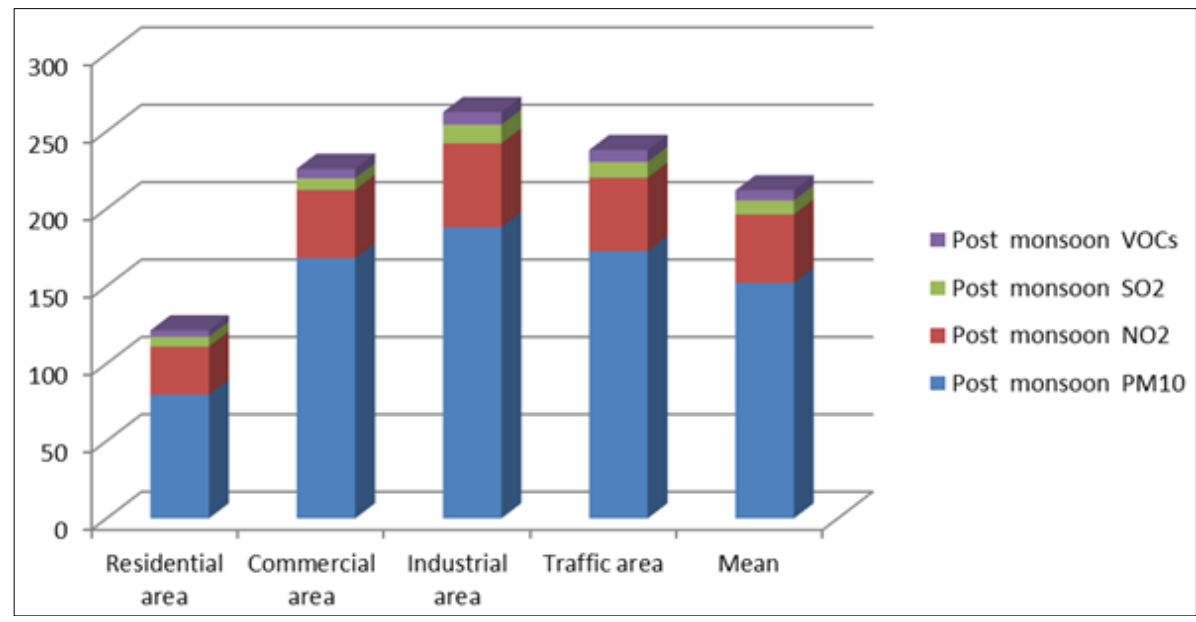

Fig 2: Concentration of air pollutants $\left(\mu \mathrm{g} / \mathrm{m}^{3}\right)$ at different locations in Baddi

Table 3: Concentration of air pollutants $\left(\mu \mathrm{g} / \mathrm{m}^{3}\right)$ at different locations in Nalagarh

\begin{tabular}{|c|c|c|c|c|}
\hline \multirow{2}{*}{ Locations } & \multicolumn{4}{|c|}{ Post monsoon } \\
\cline { 2 - 5 } & PM10 $_{\mathbf{1 0}}$ & $\mathbf{N O}_{2}$ & $\mathbf{S O}_{2}$ & VOCs \\
\hline Residential area & 73.86 & 24.08 & 5.88 & 2.86 \\
\hline Commercial area & 136.08 & 28.14 & 7.87 & 4.89 \\
\hline Industrial area & 147.09 & 35.6 & 6.85 & 6.87 \\
\hline Traffic area & 130.77 & 41.08 & 6.59 & 5.84 \\
\hline Mean & 121.95 & 32.22 & 6.79 & 5.11 \\
\hline
\end{tabular}

A perusal of data in table 3 showed the concentration of Particulate Matter $\left(\mathrm{PM}_{10}\right)$, Nitrogen dioxide $\left(\mathrm{NO}_{2}\right)$, Sulphur dioxide $\left(\mathrm{SO}_{2}\right)$ and Volatile organic compounds (VOCs) recorded during post monsoon season at different locations in Nalagarh city. The maximum mean concentration of Particulate Matter $\left(\mathrm{PM}_{10}\right)$ was recorded at industrial area with a mean value of $147.09 \mu \mathrm{g}$ per $\mathrm{m}^{3}$ followed by commercial area $\left(136.08 \mu \mathrm{g}\right.$ per $\left.\mathrm{m}^{3}\right)$ and traffic area (130.77 $\mu \mathrm{g}$ per $\left.\mathrm{m}^{3}\right)$. The minimum mean concentration of Particulate Matter $\left(\mathrm{PM}_{10}\right)$ was found to be $73.86 \mu \mathrm{g}$ per $\mathrm{m}^{3}$ at residential area. The overall mean concentration of $\mathrm{PM}_{10}$ was found $121.95 \mu \mathrm{g}$ per $\mathrm{m}^{3}$ in the city. The maximum mean concentration of
Nitrogen dioxide $\left(\mathrm{NO}_{2}\right)$ was recorded at traffic area with a mean value of $41.08 \mu \mathrm{g}$ per $\mathrm{m}^{3}$ followed by industrial area $\left(35.6 \mu \mathrm{g}\right.$ per $\left.\mathrm{m}^{3}\right)$ and commercial area $\left(28.14 \mu \mathrm{g}\right.$ per $\left.\mathrm{m}^{3}\right)$. The minimum mean concentration of Nitrogen dioxide $\left(\mathrm{NO}_{2}\right)$ was found to be $24.08 \mu \mathrm{g}$ per $\mathrm{m}^{3}$ at residential area in the city. The overall mean concentration of $\mathrm{NO}_{2}$ was found $32.22 \mu \mathrm{g}$ per $\mathrm{m}^{3}$ in the city. The maximum mean concentration of Sulphur dioxide $\left(\mathrm{SO}_{2}\right)$ was recorded at commercial area with a mean value of $7.87 \mu \mathrm{g}$ per $\mathrm{m}^{3}$ followed by industrial area $(6.85 \mu \mathrm{g}$ per $\left.\mathrm{m}^{3}\right)$ and traffic area $\left(6.59 \mu \mathrm{g}\right.$ per $\left.\mathrm{m}^{3}\right)$. The minimum mean concentration of Sulphur dioxide $\left(\mathrm{SO}_{2}\right)$ was found to be 5.88 $\mu \mathrm{g}$ per $\mathrm{m}^{3}$ at residential area. The overall mean concentration of $\mathrm{SO}_{2}$ was found $6.79 \mu \mathrm{g}$ per $\mathrm{m}^{3}$ in the city. The maximum mean concentration of Volatile organic compounds (VOCs) was recorded at industrial area with a mean value of $6.87 \mu \mathrm{g}$ per $\mathrm{m}^{3}$ followed by traffic area $\left(5.84 \mu \mathrm{g}\right.$ per $\left.\mathrm{m}^{3}\right)$ and commercial area $\left(4.89 \mu \mathrm{g}\right.$ per $\left.\mathrm{m}^{3}\right)$. The minimum mean concentration of Volatile organic compounds (VOCs) was found to be $2.86 \mu \mathrm{g}$ per $\mathrm{m}^{3}$ at residential area. The overall mean concentration of VOCs was found $5.11 \mu \mathrm{g}$ per $\mathrm{m}^{3}$ in the city. Figure 3 show the concentration of air pollutants $\left(\mu \mathrm{g} / \mathrm{m}^{3}\right)$ at different locations in Nalagarh.

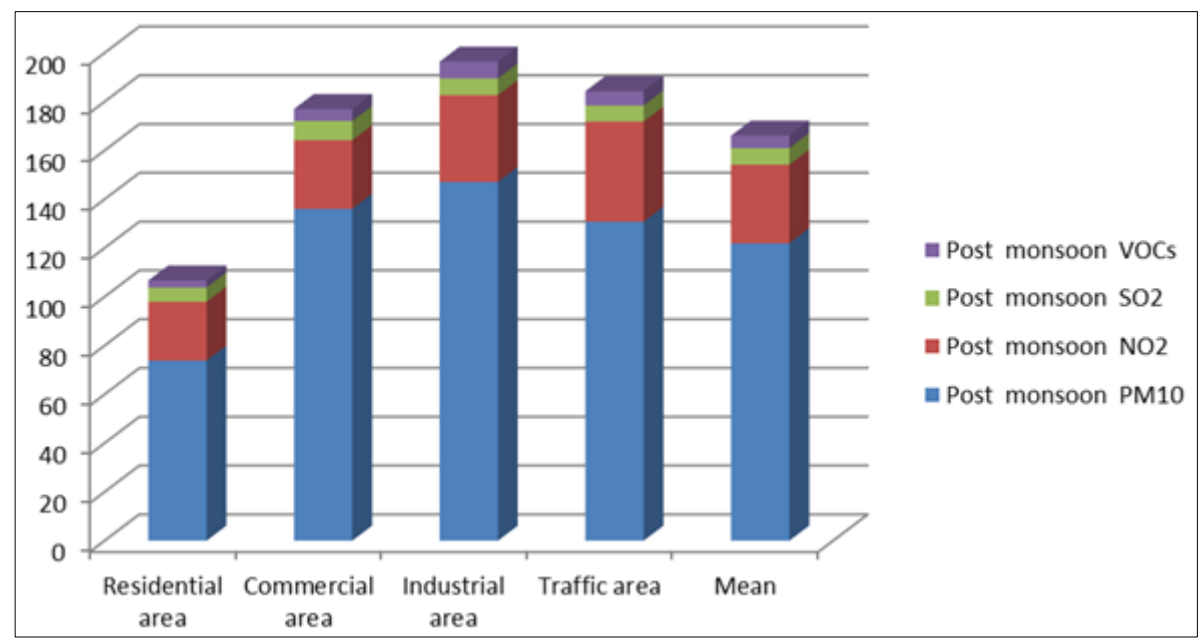

Fig 3: Concentration of air pollutants $\left(\mu \mathrm{g} / \mathrm{m}^{3}\right)$ at different locations in Nalagarh 
Table 4: Concentration of air pollutants $\left(\mu \mathrm{g} / \mathrm{m}^{3}\right)$ at different locations in Parwanoo

\begin{tabular}{|c|c|c|c|c|}
\hline \multirow{2}{*}{ Locations } & \multicolumn{4}{|c|}{ Post monsoon } \\
\cline { 2 - 5 } & $\mathbf{P M}_{\mathbf{1 0}}$ & $\mathbf{N O}_{\mathbf{2}}$ & $\mathbf{S O}_{\mathbf{2}}$ & VOCs \\
\hline Residential area & 72.41 & 22.08 & 6.87 & 1.84 \\
\hline Commercial area & 123.08 & 27.05 & 7.89 & 2.72 \\
\hline Industrial area & 133.87 & 32.06 & 10.11 & 4.31 \\
\hline Traffic area & 127.03 & 30.86 & 7.83 & 2.31 \\
\hline Mean & 114.09 & 28.01 & 8.17 & 2.79 \\
\hline
\end{tabular}

Table 4 showed the concentration of Particulate Matter $\left(\mathrm{PM}_{10}\right)$, Nitrogen dioxide $\left(\mathrm{NO}_{2}\right)$, Sulphur dioxide $\left(\mathrm{SO}_{2}\right)$ and Volatile organic compounds (VOCs) recorded during post monsoon season at different locations in Parwanoo city. The maximum mean concentration of Particulate Matter $\left(\mathrm{PM}_{10}\right)$ was recorded at industrial area with a mean value of $133.87 \mu \mathrm{g}$ per $\mathrm{m}^{3}$ followed by traffic area $\left(127.03 \mu \mathrm{g}\right.$ per $\left.\mathrm{m}^{3}\right)$ and commercial area $\left(123.08 \mu \mathrm{g}\right.$ per $\left.\mathrm{m}^{3}\right)$. The minimum mean concentration of Particulate Matter $\left(\mathrm{PM}_{10}\right)$ was found to be $72.41 \mu \mathrm{g}$ per $\mathrm{m}^{3}$ at residential area. The overall mean concentration of $\mathrm{PM}_{10}$ was found $114.09 \mu \mathrm{g}$ per $\mathrm{m}^{3}$ in the city. The maximum mean concentration of Nitrogen dioxide $\left(\mathrm{NO}_{2}\right)$ was recorded at industrial area with a mean value of $32.06 \mu \mathrm{g}$ per $\mathrm{m}^{3}$ followed by traffic area $\left(30.86 \mu \mathrm{g}\right.$ per $\left.\mathrm{m}^{3}\right)$ and commercial area $\left(27.05 \mu \mathrm{g}\right.$ per $\left.\mathrm{m}^{3}\right)$. The minimum mean concentration of Nitrogen dioxide $\left(\mathrm{NO}_{2}\right)$ was found to be $22.08 \mu \mathrm{g}$ per $\mathrm{m}^{3}$ at residential area in the city. The overall mean concentration of $\mathrm{NO}_{2}$ was found $28.01 \mu \mathrm{g}$ per $\mathrm{m}^{3}$ in the city. The maximum mean concentration of Sulphur dioxide $\left(\mathrm{SO}_{2}\right)$ was recorded at industrial area with a mean value of $10.11 \mu \mathrm{g}$ per $\mathrm{m}^{3}$ followed by commercial area $\left(7.89 \mu \mathrm{g}\right.$ per $\left.\mathrm{m}^{3}\right)$ and traffic area $\left(7.83 \mu \mathrm{g}\right.$ per $\left.\mathrm{m}^{3}\right)$. The minimum mean concentration of Sulphur dioxide $\left(\mathrm{SO}_{2}\right)$ was found to be $6.87 \mu \mathrm{g}$ per $\mathrm{m}^{3}$ at residential area. The overall mean concentration of $\mathrm{SO}_{2}$ was found $9.01 \mu \mathrm{g}$ per $\mathrm{m}^{3}$ in the city. The maximum mean concentration of Volatile organic compounds (VOCs) was recorded at industrial area with a mean value of $4.31 \mu \mathrm{g}$ per $\mathrm{m}^{3}$ followed by commercial area $\left(2.72 \mu \mathrm{g}\right.$ per $\left.\mathrm{m}^{3}\right)$ and traffic area $\left(2.31 \mu \mathrm{g}\right.$ per $\left.\mathrm{m}^{3}\right)$. The minimum mean concentration of Volatile organic compounds (VOCs) was found to be $1.84 \mu \mathrm{g}$ per $\mathrm{m}^{3}$ at residential area. The overall mean concentration of VOCs was found $2.79 \mu \mathrm{g}$ per $\mathrm{m}^{3}$ in the city. Figure 4 show the concentration of air pollutants $\left(\mu \mathrm{g} / \mathrm{m}^{3}\right)$ at different locations in Parwanoo.

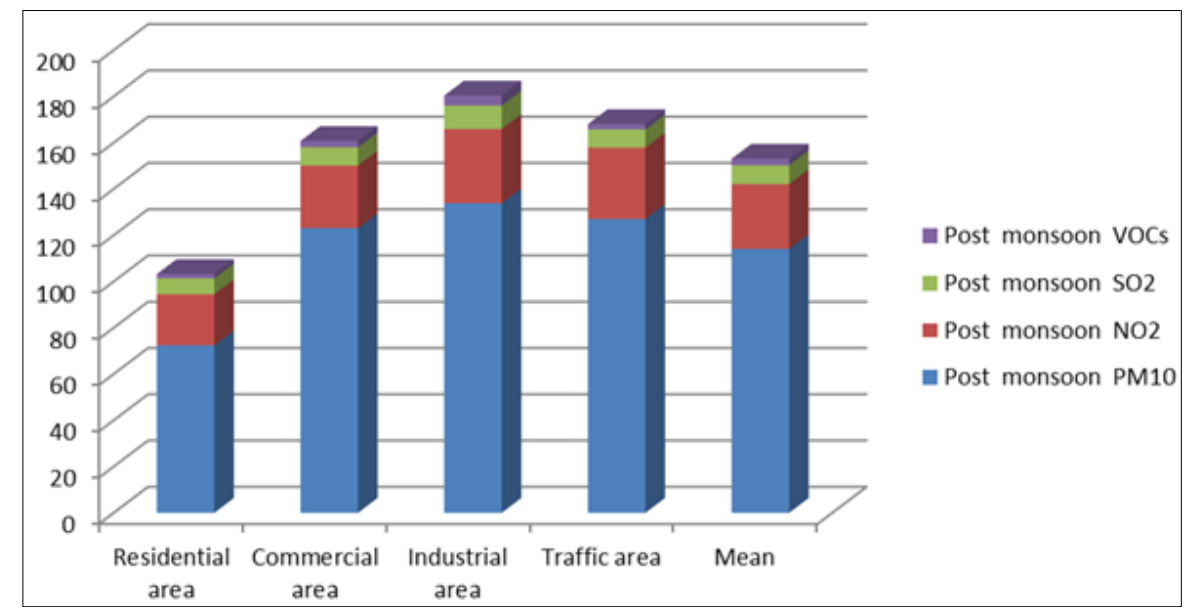

Fig 4: Concentration of air pollutants $\left(\mu \mathrm{g} / \mathrm{m}^{3}\right)$ at different locations in Parwanoo

The occurrence of maximum pollutants at commercial, industrial and traffic sites may be because of industrial activities and number of restaurants, bakery shops, food vendor outlets, prominent shopping complexes for tourists as well as for local community and continuous lines of street level shops are present around these sites in $\mathrm{BBN}$ region. Use of diesel-powered generator sets during power breakdown is also very common at these sites. Moreover, these sites repeatedly suffered from prolonged episodes of traffic congestion and stoppage throughout the day as the roads are narrow and congested. Mathew (2012) ${ }^{[13]}$ pointed out that the emissions of gases and particulates steadily increase with decrease in speed of vehicles. Higher concentrations of NO2 in winter may also result from photochemical oxidation of NO to NO2 (Gurtu et al., 2001) ${ }^{[10]}$.

The minimum concentration of pollutants was found at Mandi city where the emission of air pollutants is less in comparison to $\mathrm{BBN}$ region. The construction activities are comparatively less, the number of vehicles is less and road condition is good in the city. Moreover, sufficient vegetation is present in the city which helps in absorbing the pollutants and the air pollutants get dispersed into air easily. The data recorded for the gaseous pollutants in all the locations revealed that the concentration of gaseous pollutants (NO2, SO2 and VOCs) is well within the NAAQS (National Ambient Air Quality
Standards) limits as stipulated by Central Pollution Control Board, Government of India whereas, the concentration of suspended particulate matter is higher than the prescribed limits of National Ambient Air Quality Standards in BBN region.

\section{Conclusion}

Based on the present investigation it can be concluded that the concentrations of gaseous pollutants like $\mathrm{SO}_{2}, \mathrm{NO}_{2}$, volatile organic compounds and particulate matter in the air are within the National Ambient Air Quality Standards at all the sites in Mandi city. The industrial area of HP in Baddi-BarotiwalaNalagarh also contain gaseous pollutants like $\mathrm{SO}_{2}, \mathrm{NO}_{2}$ and volatile organic compounds within the permissible limits. However, in the Industrial region all sites like Industrial hub $\left(156.39 \mu \mathrm{g}\right.$ per $\left.\mathrm{m}^{3}\right)$, traffic $\left(143.5 \mu \mathrm{g}\right.$ per $\left.\mathrm{m}^{3}\right)$ and commercial area $\left(142.46 \mu \mathrm{g}\right.$ per $\left.\mathrm{m}^{3}\right)$ contained average concentration of particulate above the prescribed permissible limits indicating thereby that Industrial activities have started impacting the ambient air quality of our state.

\section{Recommendations}

- The roads should be maintained properly in order to reduce congestion and traffic jams. 
- Solar based battery vehicles should be used for local transportation.

- Air quality should be monitored properly.

\section{Acknowledgement}

The financial support provided by National Mission on Himalayan Studies (NMHS) G. B. Pant Institute of Himalayan Environment and Development, Ministry of Environment, Forests \& Climate Change, Almorah is highly acknowledged.

\section{References}

1. Anonymous. Alternative Policy Study: Reducing air pollution in Asia and the Pacific, Global Environment Outlook, United Nation Environment Programme 2000, 59.

2. Anonymous. World Health Report 2002: Reducing risk, Promoting healthy life, World Health Organization. Geneva, Switzerland 2004, 809.

3. Anonymous. Third Phase Research Report of the Urban Environmental Management Project 2007, 198.

4. Brulfert GT, Cholleta JP, Jouveb B, Villard H. Atmosphereic emission inventory of the Maurienne valley for an atmospheric numerical model. Science of the Total Environment 2005;349:232-248.

5. Cohen AJ, Anderson HR, Ostro B, Pandey KD, Krzyzanowski M, Kunzli N et al. Pope CA III, Romieu I, Samet JM and Smith KR. Urban air pollution. Comparative quantification of health risks: global and regional burden of disease attributable to selected major risk factors (Ezzati M, Lopez AD, Rodgers A, Murray CJL, Eds.) 2004, 1153-1433.

6. Dwivedi AK, Tripathi BD, Shashi. Effect of ambient air sulphur dioxide on sulphate accumulation in plants. Journal of Environmental Biology 2008;29:377-379.

7. Garg A, Shukla PR, Bhattacharya S, Dadhwal VK. Subregion (district) and sector level $\mathrm{SO}_{2}$ and $\mathrm{NO}_{\mathrm{X}}$ emissions for India: Assessment of inventories and mitigation flexibility. Atmospheric Environment 2001;35:703-713.

8. Ghanem M, Guo Y, Hassard J, Osmond M, Richards M. Sensor grids for air pollution monitoring. Sensors 2008;8:3601-3623.

9. Greenstone M, Hanna R. Environmental regulation, air pollution, water pollution and infant mortality in India. American Economic Review 2014;104(10):3038-3072.

10. Gurtu D, Vaidya M, Gajghate DG. World scenario of particulate matter, $\mathrm{NO}_{2}$ and $\mathrm{SO}_{2}$ : $\mathrm{A}$ review. Indian Journal of Environmental Protection 2001;21(8):683-695.

11. Mage D, Ozolins G, Peterson P, Webster A, Orthofer R, Vandeveerd V et al. Urban air pollution in mega cities of the world. Atmospheric Environment 1996;30:681-686.

12. Maheshwari SR. Local Government in India. Lakshmi Narain Agarwal Educational Publishers, Agra 2006, 675.

13. Mathew TV. Lecture note on fuel consumption and emission studies. Traffic Engineering and Management, National Programme on Technology Enhanced Learning (NPTEL) Indian Institute of Tehnology, Bombay 2012, $1-27$.

14. Mukunda RPV, Hima BV, Sagareshwar G, Jayakumar I, Anjaneyulu Y. Assessment of ambient air quality in the rapidly industrially growing Hyderabad urban environment. Workshop Program and Presentation, Air Quality Monitoring and Management, Better Air Quality (BAQ) conference 2003, 69.
15. Naik S. Studies on pollution status of Bondamunda area of Rourkela industrial complex. Department of Chemistry, National Institute of Technology, Rourkela, Odisha 2005, 365.

16. Nyberg F, Gustavsson P, Jarup L, Bellander T, Berglind $\mathrm{N}$, Jakobsson $\mathrm{R}$ et al. Comparative urban air pollution and lung cancer in India and China. Epidemiology 2000;11(5):487-495.

17. Parra R, Jimenez P, Baldasano JM. Development of the high spatial resolution EMICAT2000 emission model for air pollutants from the north-eastern Iberian Peninsula (Catalonia, Spain). Environmental Pollution 2006;140(2):200-219.

18. Smith J, Hugh P, Wigley TML. Global and regional anthropogenic sulfur dioxide emissions. Global and Planetary Change 2001;29(1-2):99-119.

19. Su TC, Chen SY, Chan CC. Progress of ambient air pollution and cardiovascular disease research in Asia. Progress in Cardiovascular Diseases 2011;53:369-378. 